\title{
Assessment of Some Heavy Metals in the Shadegan and Hawr Al Hawizea Wetland Waters from Iran
}

\author{
Hassan Nasirian ${ }^{1 *}$, Shahrokh Nazmara ${ }^{2}$, Ami Hossein Mahvii ${ }^{2,3}$, Mostafa Hosseini ${ }^{4}$, Layla Shiri ${ }^{2}$ and \\ Babak Vazirianzadeh $^{5}$ \\ 'Department of Medical Entomology and Vector Control, School of Public Health, Tehran University of Medical \\ Sciences, Tehran, Iran; hanasirian@yahoo.com \\ ${ }^{2}$ Department of Environmental Health Engineering, School of Public Health, Tehran University of Medical Sciences, \\ Tehran, Iran \\ ${ }^{3}$ Center for Solid Waste Research, Institute for Environmental Research, Tehran University of Medical Sciences, \\ Tehran, Iran \\ ${ }^{4}$ Department of Epidemiology and Biostatistics, School of Public Health, Tehran University of Medical Sciences, \\ Tehran, Iran \\ ${ }^{5}$ Health Research Institute, Infectious and Tropical Diseases Research Center and Department of Medical \\ Entomology, Ahvaz Jundishapur University of Medical Sciences, Ahvaz, Iran
}

\begin{abstract}
Background: Heavy metal contamination of wetland waters can adversely affects human health. Methods: The Arsenic (As), Cadmium (Cd), Cobalt (Co), Chromium (Cr), Copper ( $\mathrm{Cu}$ ), Iron ( $\mathrm{Fe}$ ), Mercury (Hg), Manganese (Mn), Lead (Pb), and Zinc (Zn) of Shadegan and Hawr Al Azim wetland waters in the Khuzistan Province, South Western Iran were assessed from October 2011 to September 2012. Results: Shadegan and Hawr Al Azim wetland waters were contaminated with $\mathrm{Cr}, \mathrm{Fe}, \mathrm{Mn}$, $\mathrm{Hg}$ and $\mathrm{Zn}$ as they were more than the Environmental Protection Agency (EPA) normal levels. One-sample t-test showed a significant difference between these wetland waters contaminated heavy metals and the EPA normal levels. Application: Although these wetland waters were contaminated by the mentioned heavy metals, they will likely accumulate in the fauna and flora tissues. Afterwards they were biomagnified there after their entering in the marine food chains. Finally they were fed by predators such as birds and fish and threatened human health through food chains.
\end{abstract}

Keywords: Assessment, Contamination, Heavy metal, Water, Wetland

\section{Introduction}

In recent years, the nation's water resources are threatened by the various pollutions such as industrial effluents, fertilizers, chemical pesticides, and wastewaters ${ }^{1,2}$. Protecting the wetlands such as Shadegan and Hawr Al Azim (Hawr Al Hawizea) can protect our safety and welfare $^{3}$ because they take on characteristics that make them distinct ${ }^{4 ;}$ moreover, they are the most productive ecosystem among ecosystems of the world ${ }^{5}$. Some wetlands benefits in the world are: water quality improving, water pollutant removing, flood protecting, erosion controlling, groundwater recharging, wildlife habitat providing, recreational and cultural function serving, aesthetic appreciation, creatures' biodiversity reservoirs, natural research center, tourism destination potential and local resident socioeconomic advantages ${ }^{6,7}$. Also they have eco-environmental conditions to prevent the dust phenomena that are extremely important and are a regional and interregional complex problem in the recent decades ${ }^{7}$. So wetlands need to be monitored and managed over the time to assess their ecologically functioning ${ }^{3}$. To manage wetlands effectively it is necessary to have adequate knowledge of their any pollution to ensure that there are no any contaminations ${ }^{4}$.

The various aquatic ecosystems such as wetlands are encountered to wide range of heavy metal pollution. Really it has been drawn the attention of the researchers

*Author for correspondence 
to theirs ${ }^{8}$. Heavy metals have persistent nature. As a result they are one of the major and the most widespread groups of contaminants. They eliminate slowly from environment $^{9-11}$. In this respect contaminating the wetland waters with the metals can adversely affect on human health for their water supply and support agricultural activities. Various harmful effects including abnormal development of the fetus, procreation failure, and immunodeficiency have exhibited due to aquatic metal exposure ${ }^{12}$. So, having a strategy and plan for the water conservation and pollution control is as an issue in the country's infrastructure $^{1}$ such as wetlands. Also the aquatic organisms and wildlife are dependent to their water quality habitats. They encountered to the serious threats especially the endangered or the threatened species such as insects or other organisms. However, as mentioned protecting the wetlands in turn can protect our safety and welfare. Also the protection of threatened and endangered species is important in normal developments ${ }^{13}$.

Shadegan and Hawr Al Azim wetlands in Khuzistan Province, South West of Iran, are considered to be the most special ecosystems in the world, as mentioned the above with some various benefits. They have excellent natural attraction and create annually an appropriate habitat for a large number of migratory birds arriving from Northern Europe, Canada and Siberia. Their wildlife and natures are threatened by different kinds of pollutants such as industrial and urban wastes. Also the peoples may be suffering from Mosquito-borne diseases and their nuisance by high density of mosquito emerging ${ }^{14}$ preventing tourist activities. It is necessary to be measured the water heavy metals to inform human for preventing or reducing their water pollution which they can be searched by regular environmental surveys. In this regard annually various studies must be taken. However, few studies were done on our country wetland waters. Farrokhian et al. ${ }^{15}$ measured the Cadmium, Lead, Nickel and Copper of Shadegan wetland in a relatively old study ${ }^{15}$. In a very small and short time scales, Nasirian et al. ${ }^{7,16}$ stated that Shadegan wetland waters were contaminated by some heavy metals ${ }^{16}$. Whereas the trend of the wetland water heavy metal contamination would not be evaluated by this study. But it seems it would be better the study is taken in a large and long time scales to evaluate the trend of the wetland water heavy metal contamination. Thus in this regard the present study was done to assess the water heavy metals of Shadegan and Hawr Al Azim wetlands in Khuzistan Province, South Western Iran from October 2011 to September 2012.

\section{Materials and Methods}

\subsection{Geographical Information}

This study was carried out in Shadegan and Hawr Al Hawizea or Hawr Al Azim wetlands with a hot and humid climate in Khuzistan Province, South Western Iran. Shadegan wetland is known as the largest wetland in Iran and contains an area of 537,700 hectares, placed $52 \mathrm{~km}$ far from Abadan and $40 \mathrm{~km}$ far from Ahvaz and closed from North to Shadegan city and Khor Doraq, from South to Bahmanshir river, from West to Darkhovien and Abadan road and from East to Khure-Musa. It is mainly supplied by Karoun river waters. The coordinates of Shadegan wetland area are: $48^{\circ} 17^{\prime}-48^{\circ} 50^{\prime} \mathrm{E} 30^{\circ} 17^{\prime}-30^{\circ} 58^{\prime} \mathrm{N}^{7,16}$.

Hawr Al Azim and Hawr Al Hawizeh are parts of a single hydrologic system forming the largest permanent freshwater wetlands in Lower Mesopotamia and situating in the North Azadegan Plain, $80 \mathrm{~km}$ Southwest of Ahvaz County, near the border between Iran and Iraq. They covers an area of about 56654 hectares, most (37266 hectares) of which locates within the Hawr Al Azim wetland. Their coordinates are: $47^{\circ} 20^{\prime}-47^{\circ} 55^{\prime} \mathrm{E}-30^{\circ} 58^{\prime}-31^{\circ} 50^{\prime} \mathrm{N}^{17}$.

\subsection{Site Selection}

The water samplings were conducted from six different sites including: 1. Water canal entrance to Shadegan Wetland $\left(\mathrm{SW}_{1}\right)$ located at the West of the wetland between Darkhovien city and wetland at $15 \mathrm{~km}$ of ShadeganDarkhovien road where waste output of sugarcane expansion plan released into the wetland. 2. The middle of Shadegan Wetland area $\left(\mathrm{SW}_{2}\right)$ located at $10 \mathrm{~km}$ in its middling of this wetland. 3. Ragbeh and Sarakhieh villages surrounding and tourism station of Shadegan Wetland areas $\left(\mathrm{SW}_{3}\right)$ located at the West of the wetland at $5 \mathrm{~km}$ of ShadeganDarkhovien road. 4. Waste output from sugarcane expansion plan $\left(\mathrm{SW}_{4}\right)$ located at the North Western of the wetland at $40 \mathrm{~km}$ of Ahvaz-Abadan road where waste output of sugarcane expansion plan comes out. 5. The entry of Shadegan city wastewater to Shadegan Wetland $\left(\mathrm{SW}_{5}\right)$ located between Shadegan city and wetland at the East of the wetland where urban waste released into the wetland. 6 . The wide middle area of Hawr Al Hawizeh or Hawr Al Azim wetland (HH) located at $10 \mathrm{~km}$ in its middling of this wetland ${ }^{18}$.

\subsection{Water Sampling}

Water samples were collected using one liter acid-washed (10\% Nitric acid) poly-ethylene containers. Then $1 \mathrm{ml}$ 
concentrated Nitric acid $\left(\mathrm{HNO}_{3}\right)$ was added to each sample and transported to the laboratory after labeling and packaging.

\subsection{ICP-OES Metal Analysis}

The water samples for metals testing including Arsenic(As), Cadmium (Cd), Cobalt (Co), Chromium (Cr), Copper $(\mathrm{Cu})$, Iron $(\mathrm{Fe})$, Mercury $(\mathrm{Hg})$, Manganese $(\mathrm{Mn})$, Lead $(\mathrm{Pb})$, and Zinc $(\mathrm{Zn})$ were subjected to ICP-OES (Germany SPECTRO Company, Spectro ARCOS Model) instrument to quantify the composition of the given samples ${ }^{19}$.

\subsection{Statistical Analysis}

Data concerning the investigated water metal pollutants between the different selected sites and dates and between the selected sites and months were analyzed by One-way analysis of variance (ANOVA) followed by Post Hoc tests (Tukey HSD), respectively using PASW Statistics 18. Onesample t-test was used for comparing the water metal pollutants with the Environmental Protection Agency (EPA) normal levels ${ }^{20}$.

\subsection{Results and Discussion}

Tables 1 and 2 shows the water heavy metals which were measured in the different selected sites of Shadegan and Hawr Al Azim wetlands by $\mu \mathrm{g} / \mathrm{L}$ and $\mu \mathrm{g} / \mathrm{g}$ from October 2011 to September 2012. Generally, the levels of As, Cd, $\mathrm{Co}, \mathrm{Cu}$ and $\mathrm{Pb}$ in the water which were sampled monthly from different sites of both wetlands during October 2011 to September 2012, were observed lower than the EPA water standards. This fact indicates that the water has not been contaminated by these metals; whereas the values of $\mathrm{Cr}, \mathrm{Fe}, \mathrm{Mn}, \mathrm{Hg}$, and $\mathrm{Zn}$ in some month samplings were higher than the EPA water normal levels (shown in bold in the Tables 1 and 2). This fact indicates that the waters of these wetlands have been contaminated by these heavy metals (Tables 1 and 2). Also Figure 1 show trends of the investigated water heavy metals $(\mu \mathrm{g} / \mathrm{g})$ in the different selected sites of Shadegan and Hawr Al Azim wetlands, from October 2011 to September 2012.

The water $\mathrm{Cr}$ values in the $\mathrm{SW}_{1}$ and $\mathrm{SW}_{5}$ in the October, December and September; the $\mathrm{SW}_{2}, \mathrm{SW}_{3}$ and $\mathrm{SW}_{4}$ in the October, December, March, April and September; and the $\mathrm{HH}$ in the October observed higher than the EPA normal levels ${ }^{20}$ indicating water contamination to $\mathrm{Cr}$ (shown in bold in the Tables 1 and 2). The lowest and the

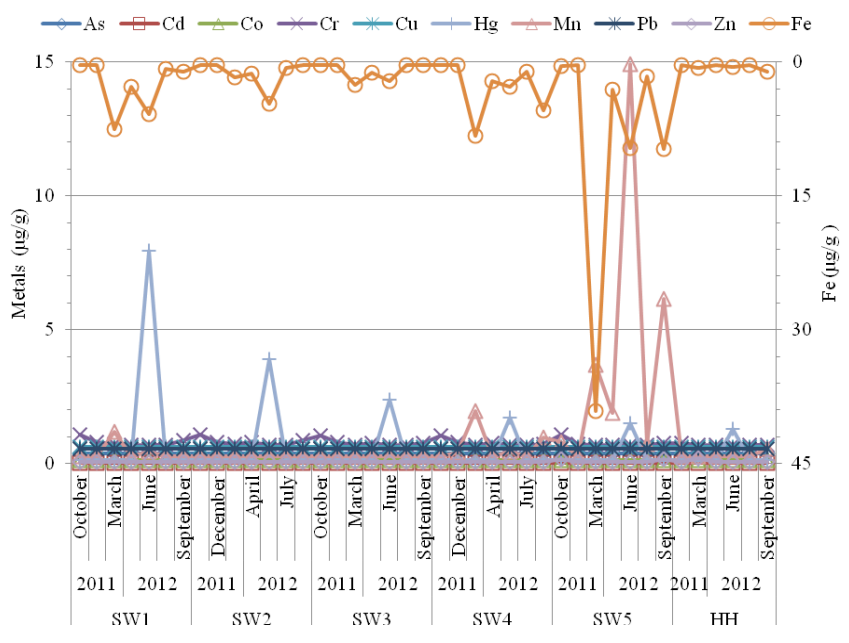

Figure 1. Trends of the water heavy metals investigated $(\mu \mathrm{g} / \mathrm{g})$ in the different selected sites of Shadegan and Hawr Al Azim Wetlands, from October 2011 to September 2012.

highest water contamination $\mathrm{Cr}$ values observed in the $\mathrm{SW}_{3}$ and $\mathrm{SW}_{4}$, and in the $\mathrm{SW}_{2}$ and $\mathrm{SW}_{5}$ in the March and October, respectively (Tables 1 and 2, and Figure 1). The results of one-sample t-test revealed a significant differences between the water $\mathrm{Cr}$ values and EPA normal levels $(\mathrm{P}<0.0001)$ Table $3^{20}$. The results of one-way analysis of variance (ANOVA) did not show any significant differences between the $\mathrm{Cr}$ values of the sites $(\mathrm{P}=0.056)$, whereas it showed a significant differences between the $\mathrm{Cr}$ values of the months $(\mathrm{P}<0.0001)$ (Table 4). Also Post Hoc tests (Tukey HSD) showed a significant differences between the $\mathrm{Cr}$ values of the $\mathrm{HH}$ with the $\mathrm{SW}_{1}, \mathrm{SW}_{2}, \mathrm{SW}_{3}, \mathrm{SW}_{4}$ and $\mathrm{SW}_{5}$; and October with the other months; December with the March, April, June and July; and September with the March, June and July $(\mathrm{P}<0.05)$, whereas they did not show any significant differences between the other sites and months $(\mathrm{P}>0.05)$ (Tables 5 and 6).

The water Fe values of the $\mathrm{SW}_{1}$ and $\mathrm{SW}_{4}$ in the March, April, June, July, September; the $\mathrm{SW}_{2}$ and $\mathrm{SW}_{3}$ (except July) in the March, April, June and July; the $\mathrm{SW}_{5}$ in the all months (except the July); and the HH in the March, June and September observed higher than the EPA normal lev$\mathrm{els}^{20}$ indicating water contamination to $\mathrm{Fe}$ (shown in bold in the Tables 1 and 2). The lowest and the highest water Fe contamination values observed both in the $\mathrm{SW}_{5}$ in the October and March (Tables 1 and 2, and Figure 1). The results of one-sample t-test revealed a significant differences between the Fe values of the sites and months with the EPA normal levels $(\mathrm{P}<0.0001)$ Table 3 . Also the results 
Table 1. Water heavy metals investigated $(\mu \mathrm{g} / \mathrm{L})$ in the different selected sites of Shadegan and Hawr Al Azim Wetlands, from October 2011 to September 2012

\begin{tabular}{|c|c|c|c|c|c|c|c|c|c|c|c|c|}
\hline \multirow{2}{*}{$\stackrel{\oplus}{*}$} & \multirow{2}{*}{ Season } & \multirow{2}{*}{ Month } & \multicolumn{10}{|c|}{ Heavy metal } \\
\hline & & & As & $\mathrm{Cd}$ & Co & $\mathrm{Cr}$ & $\mathrm{Cu}$ & $\mathrm{Fe}$ & $\mathrm{Hg}$ & Mn & $\mathrm{Pb}$ & $\mathrm{Zn}$ \\
\hline \multirow{7}{*}{$\sum_{\infty}$} & \multirow[t]{2}{*}{ Autumn } & October & $<15.32$ & $<1.11$ & $<4.98$ & 38.86 & $<24.59$ & $<15.77$ & $<5.63$ & $<10.39$ & $<22.33$ & $<2.17$ \\
\hline & & December & $<15.32$ & $<1.11$ & $<4.98$ & 28.02 & $<24.59$ & $<15.77$ & $<5.63$ & $<10.39$ & $<22.33$ & $<2.17$ \\
\hline & Winter & March & $<15.32$ & $<1.11$ & $<4.98$ & 26.42 & $<24.59$ & 305.29 & $<5.63$ & 47.09 & $<22.33$ & $<2.17$ \\
\hline & \multirow[t]{2}{*}{ Spring } & April & $<15.32$ & $<1.11$ & $<4.98$ & $<24.49$ & $<24.59$ & 111 & $<5.63$ & 11 & $<22.33$ & $<2.17$ \\
\hline & & June & $<15.32$ & $<1.11$ & $<4.98$ & $<24.49$ & $<24.59$ & 235 & 319 & 18 & $<22.33$ & $<2.17$ \\
\hline & \multirow[t]{2}{*}{ Summer } & July & $<15.32$ & $<1.11$ & $<4.98$ & $<24.49$ & $<24.59$ & 31.15 & $<5.63$ & $<10.39$ & $<22.33$ & $<2.17$ \\
\hline & & September & $<15.32$ & $<1.11$ & $<4.98$ & 30.89 & $<24.59$ & 42.24 & $<5.63$ & $<10.39$ & $<22.33$ & $<2.17$ \\
\hline \multirow{7}{*}{$\sum_{i s}^{N}$} & \multirow[t]{2}{*}{ Autumn } & October & $<15.32$ & $<1.11$ & $<4.98$ & 39.11 & $<24.59$ & $<15.77$ & $<5.63$ & $<10.39$ & $<22.33$ & $<2.17$ \\
\hline & & December & $<15.32$ & $<1.11$ & $<4.98$ & 28.70 & $<24.59$ & $<15.77$ & $<5.63$ & $<10.39$ & $<22.33$ & $<2.17$ \\
\hline & Winter & March & $<15.32$ & $<1.11$ & $<4.98$ & 26 & $<24.59$ & 67.58 & $<5.63$ & $<10.39$ & $<22.33$ & $<2.17$ \\
\hline & \multirow[t]{2}{*}{ Spring } & April & $<15.32$ & $<1.11$ & $<4.98$ & 28 & $<24.59$ & 51 & $<5.63$ & $<10.39$ & $<22.33$ & $<2.17$ \\
\hline & & June & $<15.32$ & $<1.11$ & $<4.98$ & $<24.49$ & $<24.59$ & 190 & 157 & $<10.39$ & $<22.33$ & $<2.17$ \\
\hline & \multirow[t]{2}{*}{ Summer } & July & $<15.32$ & $<1.11$ & $<4.98$ & $<24.49$ & $<24.59$ & 26.89 & $<5.63$ & $<10.39$ & $<22.33$ & $<2.17$ \\
\hline & & September & $<15.32$ & $<1.11$ & $<4.98$ & 30.51 & $<24.59$ & $<15.77$ & $<5.63$ & $<10.39$ & $<22.33$ & $<2.17$ \\
\hline \multirow{7}{*}{$\sum_{\infty}^{m}$} & \multirow[t]{2}{*}{ Autumn } & October & $<15.32$ & $<1.11$ & $<4.98$ & 38.06 & $<24.59$ & $<15.77$ & $<5.63$ & $<10.39$ & $<22.33$ & $<2.17$ \\
\hline & & December & $<15.32$ & $<1.11$ & $<4.98$ & 29.18 & $<24.59$ & $<15.77$ & $<5.63$ & $<10.39$ & $<22.33$ & $<2.17$ \\
\hline & Winter & March & $<15.32$ & $<1.11$ & $<4.98$ & 24.97 & $<24.59$ & 102.33 & $<5.63$ & $<10.39$ & $<22.33$ & $<2.17$ \\
\hline & \multirow[t]{2}{*}{ Spring } & April & $<15.32$ & $<1.11$ & $<4.98$ & 27 & $<24.59$ & 48 & $<5.63$ & $<10.39$ & $<22.33$ & $<2.17$ \\
\hline & & June & $<15.32$ & $<1.11$ & $<4.98$ & $<24.49$ & $<24.59$ & 88 & 96 & $<10.39$ & $<22.33$ & $<2.17$ \\
\hline & \multirow[t]{2}{*}{ Summer } & July & $<15.32$ & $<1.11$ & $<4.98$ & $<24.49$ & $<24.59$ & $<15.77$ & $<5.63$ & $<10.39$ & $<22.33$ & $<2.17$ \\
\hline & & September & $<15.32$ & $<1.11$ & $<4.98$ & 27.39 & $<24.59$ & $<15.77$ & $<5.63$ & $<10.39$ & $<22.33$ & $<2.17$ \\
\hline \multirow{7}{*}{$\sum_{\infty}^{+}$} & \multirow[t]{2}{*}{ Autumn } & October & $<15.32$ & $<1.11$ & $<4.98$ & 38.19 & $<24.59$ & $<15.77$ & $<5.63$ & $<10.39$ & $<22.33$ & $<2.17$ \\
\hline & & December & $<15.32$ & $<1.11$ & $<4.98$ & 29.24 & $<24.59$ & $<15.77$ & $<5.63$ & 15.8 & $<22.33$ & $<2.17$ \\
\hline & Winter & March & $<15.32$ & $<1.11$ & $<4.98$ & 24.94 & $<24.59$ & 333.04 & $<5.63$ & 78.45 & $<22.33$ & $<2.17$ \\
\hline & \multirow[t]{2}{*}{ Spring } & April & $<15.32$ & $<1.11$ & $<4.98$ & 27 & $<24.59$ & 88 & $<5.63$ & $<10.39$ & $<22.33$ & $<2.17$ \\
\hline & & June & $<15.32$ & $<1.11$ & $<4.98$ & $<24.49$ & $<24.59$ & 113 & 69 & 18 & $<22.33$ & $<2.17$ \\
\hline & \multirow[t]{2}{*}{ Summer } & July & $<15.32$ & $<1.11$ & $<4.98$ & $<24.49$ & $<24.59$ & 44.14 & $<5.63$ & $<10.39$ & $<22.33$ & $<2.17$ \\
\hline & & September & $<15.32$ & $<1.11$ & $<4.98$ & 25.71 & $<24.59$ & 220.21 & $<5.63$ & 39.12 & $<22.33$ & $<2.17$ \\
\hline & Autumn & October & $<15.32$ & $<1.11$ & $<4.98$ & 39.15 & $<24.59$ & 17.44 & $<5.63$ & 32.13 & $<22.33$ & 7.4 \\
\hline & & December & $<15.32$ & $<1.11$ & $<4.98$ & 26.73 & $<24.59$ & $<15.77$ & $<5.63$ & $<10.39$ & $<22.33$ & $<2.17$ \\
\hline & Winter & March & $<15.32$ & $<1.11$ & $<4.98$ & $<24.49$ & $<24.59$ & 1581.57 & $<5.63$ & 148.06 & $<22.33$ & $<2.17$ \\
\hline$\sum_{\infty}^{\infty}$ & Spring & April & $<15.32$ & $<1.11$ & $<4.98$ & $<24.49$ & $<24.59$ & 121 & $<5.63$ & 76 & $<22.33$ & $<2.17$ \\
\hline & & June & $<15.32$ & $<1.11$ & $<4.98$ & $<24.49$ & $<24.59$ & 391 & 60 & 596 & $<22.33$ & $<2.17$ \\
\hline & Summer & July & $<15.32$ & $<1.11$ & $<4.98$ & $<24.49$ & $<24.59$ & 64.73 & $<5.63$ & 28.83 & $<22.33$ & $<2.17$ \\
\hline & & September & $<15.32$ & $<1.11$ & $<4.98$ & 27.62 & $<24.59$ & 395.13 & $<5.63$ & 245.36 & $<22.33$ & 6.87 \\
\hline & Autumn & December & $<15.32$ & $<1.11$ & $<4.98$ & 27.45 & $<24.59$ & $<15.77$ & $<5.63$ & $<10.39$ & $<22.33$ & $<2.17$ \\
\hline & Winter & March & $<15.32$ & $<1.11$ & $<4.98$ & $<24.49$ & $<24.59$ & 25.71 & $<5.63$ & $<10.39$ & $<22.33$ & 7.68 \\
\hline$\Xi$ & Spring & April & $<15.32$ & $<1.11$ & $<4.98$ & $<24.49$ & $<24.59$ & $<15.77$ & $<5.63$ & $<10.39$ & $<22.33$ & $<2.17$ \\
\hline I & & June & $<15.32$ & $<1.11$ & $<4.98$ & $<24.49$ & $<24.59$ & 24 & 52 & $<10.39$ & $<22.33$ & $<2.17$ \\
\hline & Summer & July & $<15.32$ & $<1.11$ & $<4.98$ & $<24.49$ & $<24.59$ & $<15.77$ & $<5.63$ & $<10.39$ & $<22.33$ & $<2.17$ \\
\hline & & September & $<15.32$ & $<1.11$ & $<4.98$ & $<24.49$ & $<24.59$ & 44.23 & $<5.63$ & 21.43 & $<22.33$ & $<2.17$ \\
\hline & evice detec & ion limit & 15.32 & 1.11 & 4.98 & 24.49 & 24.59 & 15.77 & 5.63 & 10.39 & 22.33 & 2.17 \\
\hline & EPA norm & 1 level & 10 & 5 & 500 & 100 & 1300 & 300 & 2 & 50 & 15 & 5000 \\
\hline
\end{tabular}


Table 2. Water heavy metals investigated $(\mu \mathrm{g} / \mathrm{g})$ in the selected sites of Shadegan and Hawr Al Azim Wetlands, from October 2011 to September 2012

\begin{tabular}{|c|c|c|c|c|c|c|c|c|c|c|c|c|}
\hline \multirow{2}{*}{ 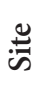 } & \multirow{2}{*}{ Season } & \multirow{2}{*}{ Month } & \multicolumn{10}{|c|}{ Heavy metal } \\
\hline & & & As & $\mathrm{Cd}$ & Co & $\mathrm{Cr}$ & $\mathrm{Cu}$ & $\mathrm{Fe}$ & $\mathrm{Hg}$ & Mn & $\mathrm{Pb}$ & $\mathrm{Zn}$ \\
\hline \multirow{7}{*}{$\sum_{\infty}$} & \multirow[t]{2}{*}{ Autumn } & October & $<0.38$ & $<0.03$ & $<0.12$ & 1.08 & $<0.62$ & $<0.39$ & $<0.14$ & $<0.26$ & $<0.56$ & $<0.05$ \\
\hline & & December & $<0.38$ & $<0.03$ & $<0.12$ & 0.78 & $<0.62$ & $<0.39$ & $<0.14$ & $<0.26$ & $<0.56$ & $<0.05$ \\
\hline & Winter & March & $<0.38$ & $<0.03$ & $<0.12$ & 0.73 & $<0.62$ & 7.55 & $<0.14$ & 1.18 & $<0.56$ & $<0.05$ \\
\hline & \multirow[t]{2}{*}{ Spring } & April & $<0.38$ & $<0.03$ & $<0.12$ & $<0.68$ & $<0.62$ & 2.74 & $<0.14$ & 0.28 & $<0.56$ & $<0.05$ \\
\hline & & June & $<0.38$ & $<0.03$ & $<0.12$ & $<0.68$ & $<0.62$ & 5.81 & 7.93 & 0.45 & $<0.56$ & $<0.05$ \\
\hline & \multirow[t]{2}{*}{ Summer } & July & $<0.38$ & $<0.03$ & $<0.12$ & $<0.68$ & $<0.62$ & 0.77 & $<0.14$ & $<0.26$ & $<0.56$ & $<0.05$ \\
\hline & & September & $<0.38$ & $<0.03$ & $<0.12$ & 0.86 & $<0.62$ & 1.04 & $<0.14$ & $<0.26$ & $<0.56$ & $<0.05$ \\
\hline \multirow{7}{*}{$\sum_{\infty}^{N}$} & \multirow[t]{2}{*}{ Autumn } & October & $<0.38$ & $<0.03$ & $<0.12$ & 1.09 & $<0.62$ & $<0.39$ & $<0.14$ & $<0.26$ & $<0.56$ & $<0.05$ \\
\hline & & December & $<0.38$ & $<0.03$ & $<0.12$ & 0.81 & $<0.62$ & $<0.39$ & $<0.14$ & $<0.26$ & $<0.56$ & $<0.05$ \\
\hline & Winter & March & $<0.38$ & $<0.03$ & $<0.12$ & 0.72 & $<0.62$ & 1.67 & $<0.14$ & $<0.26$ & $<0.56$ & $<0.05$ \\
\hline & \multirow[t]{2}{*}{ Spring } & April & $<0.38$ & $<0.03$ & $<0.12$ & 0.78 & $<0.62$ & 1.26 & $<0.14$ & $<0.26$ & $<0.56$ & $<0.05$ \\
\hline & & June & $<0.38$ & $<0.03$ & $<0.12$ & $<0.68$ & $<0.62$ & 4.71 & 3.9 & $<0.26$ & $<0.56$ & $<0.05$ \\
\hline & \multirow[t]{2}{*}{ Summer } & July & $<0.38$ & $<0.03$ & $<0.12$ & $<0.68$ & $<0.62$ & 0.66 & $<0.14$ & $<0.26$ & $<0.56$ & $<0.05$ \\
\hline & & September & $<0.38$ & $<0.03$ & $<0.12$ & 0.85 & $<0.62$ & $<0.39$ & $<0.14$ & $<0.26$ & $<0.56$ & $<0.05$ \\
\hline \multirow{7}{*}{$\sum_{\infty}^{m}$} & \multirow[t]{2}{*}{ Autumn } & October & $<0.38$ & $<0.03$ & $<0.12$ & 1.06 & $<0.62$ & $<0.39$ & $<0.14$ & $<0.26$ & $<0.56$ & $<0.05$ \\
\hline & & December & $<0.38$ & $<0.03$ & $<0.12$ & 0.81 & $<0.62$ & $<0.39$ & $<0.14$ & $<0.26$ & $<0.56$ & $<0.05$ \\
\hline & Winter & March & $<0.38$ & $<0.03$ & $<0.12$ & 0.69 & $<0.62$ & 2.53 & $<0.14$ & $<0.26$ & $<0.56$ & $<0.05$ \\
\hline & \multirow[t]{2}{*}{ Spring } & April & $<0.38$ & $<0.03$ & $<0.12$ & 0.75 & $<0.62$ & 1.19 & $<0.14$ & $<0.26$ & $<0.56$ & $<0.05$ \\
\hline & & June & $<0.38$ & $<0.03$ & $<0.12$ & $<0.68$ & $<0.62$ & 2.18 & 2.39 & $<0.26$ & $<0.56$ & $<0.05$ \\
\hline & \multirow[t]{2}{*}{ Summer } & July & $<0.38$ & $<0.03$ & $<0.12$ & $<0.68$ & $<0.62$ & $<0.39$ & $<0.14$ & $<0.26$ & $<0.56$ & $<0.05$ \\
\hline & & September & $<0.38$ & $<0.03$ & $<0.12$ & 0.76 & $<0.62$ & $<0.39$ & $<0.14$ & $<0.26$ & $<0.56$ & $<0.05$ \\
\hline \multirow{7}{*}{$\sum_{\infty}^{+}$} & \multirow[t]{2}{*}{ Autumn } & October & $<0.38$ & $<0.03$ & $<0.12$ & 1.06 & $<0.62$ & $<0.39$ & $<0.14$ & $<0.26$ & $<0.56$ & $<0.05$ \\
\hline & & December & $<0.38$ & $<0.03$ & $<0.12$ & 0.81 & $<0.62$ & $<0.39$ & $<0.14$ & 0.40 & $<0.56$ & $<0.05$ \\
\hline & Winter & March & $<0.38$ & $<0.03$ & $<0.12$ & 0.69 & $<0.62$ & 8.24 & $<0.14$ & 1.96 & $<0.56$ & $<0.05$ \\
\hline & \multirow[t]{2}{*}{ Spring } & April & $<0.38$ & $<0.03$ & $<0.12$ & 0.75 & $<0.62$ & 2.18 & $<0.14$ & $<0.26$ & $<0.56$ & $<0.05$ \\
\hline & & June & $<0.38$ & $<0.03$ & $<0.12$ & $<0.68$ & $<0.62$ & 2.8 & 1.72 & 0.45 & $<0.56$ & $<0.05$ \\
\hline & \multirow[t]{2}{*}{ Summer } & July & $<0.38$ & $<0.03$ & $<0.12$ & $<0.68$ & $<0.62$ & 1.09 & $<0.14$ & $<0.26$ & $<0.56$ & $<0.05$ \\
\hline & & September & $<0.38$ & $<0.03$ & $<0.12$ & 0.71 & $<0.62$ & 5.45 & $<0.14$ & 0.98 & $<0.56$ & $<0.05$ \\
\hline & Autumn & October & $<0.38$ & $<0.03$ & $<0.12$ & 1.09 & $<0.62$ & 0.43 & $<0.14$ & 0.8 & $<0.56$ & 0.17 \\
\hline & & December & $<0.38$ & $<0.03$ & $<0.12$ & 0.74 & $<0.62$ & $<0.39$ & $<0.14$ & $<0.26$ & $<0.56$ & $<0.05$ \\
\hline & Winter & March & $<0.38$ & $<0.03$ & $<0.12$ & $<0.68$ & $<0.62$ & 39.11 & $<0.14$ & 3.7 & $<0.56$ & $<0.05$ \\
\hline 3 & Spring & April & $<0.38$ & $<0.03$ & $<0.12$ & $<0.68$ & $<0.62$ & 3.09 & $<0.14$ & 1.9 & $<0.56$ & $<0.05$ \\
\hline & & June & $<0.38$ & $<0.03$ & $<0.12$ & $<0.68$ & $<0.62$ & 9.67 & 1.49 & 14.91 & $<0.56$ & $<0.05$ \\
\hline & Summer & July & $<0.38$ & $<0.03$ & $<0.12$ & $<0.68$ & $<0.62$ & 1.6 & $<0.14$ & $<0.26$ & $<0.56$ & $<0.05$ \\
\hline & & September & $<0.38$ & $<0.03$ & $<0.12$ & 0.77 & $<0.62$ & 9.77 & $<0.14$ & 6.15 & $<0.56$ & 0.16 \\
\hline & Autumn & December & $<0.38$ & $<0.03$ & $<0.12$ & 0.76 & $<0.62$ & $<0.39$ & $<0.14$ & $<0.26$ & $<0.56$ & $<0.05$ \\
\hline & Winter & March & $<0.38$ & $<0.03$ & $<0.12$ & $<0.68$ & $<0.62$ & 0.64 & $<0.14$ & $<0.26$ & $<0.56$ & 0.18 \\
\hline$I$ & Spring & April & $<0.38$ & $<0.03$ & $<0.12$ & $<0.68$ & $<0.62$ & $<0.39$ & $<0.14$ & $<0.26$ & $<0.56$ & $<0.05$ \\
\hline I & & June & $<0.38$ & $<0.03$ & $<0.12$ & $<0.68$ & $<0.62$ & 0.59 & 1.29 & $<0.26$ & $<0.56$ & $<0.05$ \\
\hline & Summer & July & $<0.38$ & $<0.03$ & $<0.12$ & $<0.68$ & $<0.62$ & $<0.39$ & $<0.14$ & $<0.26$ & $<0.56$ & $<0.05$ \\
\hline & & September & $<0.38$ & $<0.03$ & $<0.12$ & $<0.68$ & $<0.62$ & 1.09 & $<0.14$ & 0.54 & $<0.56$ & $<0.05$ \\
\hline & evice detec & ion limit & 0.38 & 0.03 & 0.12 & 0.68 & 0.62 & 0.39 & 0.14 & 0.26 & 0.56 & 0.05 \\
\hline & EPA norm & al level & 0.01 & 0.005 & 0.5 & 0.1 & 1.3 & 0.3 & 0.002 & 0.05 & 0.015 & 5 \\
\hline
\end{tabular}


Table 3. One-sample t-test analysis between the EPA normal levels and observed water heavy metal rates of the different selected site and month samplings

\begin{tabular}{|c|c|c|c|c|c|c|c|c|c|}
\hline \multirow{2}{*}{ Metal } & \multicolumn{3}{|c|}{ Water } & \multicolumn{3}{c|}{ Selected site } & \multicolumn{3}{c|}{ Month } \\
\cline { 2 - 11 } & $\mathbf{t}$ & $\mathbf{d f}$ & $\mathbf{P}$ & $\mathbf{t}$ & $\mathbf{d f}$ & $\mathbf{P}$ & $\mathbf{t}$ & $\mathbf{d f}$ & $\mathbf{P}$ \\
\hline $\mathrm{Cr}$ & 0.72 & 40 & 0.476 & 10.21 & 41 & $<0.0001$ & 10.31 & 41 & $<0.0001$ \\
\hline $\mathrm{Fe}$ & 2.35 & 40 & 0.024 & 10.54 & 41 & $<0.0001$ & 10.61 & 41 & $<0.0001$ \\
\hline $\mathrm{Hg}$ & 1.99 & 40 & 0.053 & 12.59 & 41 & $<0.0001$ & 12.35 & 41 & $<0.0001$ \\
\hline $\mathrm{Mn}$ & 1.81 & 40 & 0.078 & 11.96 & 41 & $<0.0001$ & 11.81 & 41 & $<0.0001$ \\
\hline $\mathrm{Zn}$ & 1007.6 & 40 & $<0.0001$ & 5.81 & 41 & $<0.0001$ & 3.36 & 41 & 0.002 \\
\hline
\end{tabular}

Table 4. One-way ANOVA analysis between the different selected site and month samplings of the observed water heavy metal rates

\begin{tabular}{|c|c|c|c|c|c|c|}
\hline \multirow{2}{*}{ Metal } & \multicolumn{3}{|c|}{ Selected site } & \multicolumn{3}{c|}{ Month } \\
\cline { 2 - 7 } & $\mathbf{F}$ & df & P & F & df & P \\
\hline Cr & 2.46 & 5 & 0.056 & 90.42 & 6 & $<0.0001$ \\
\hline $\mathrm{Fe}$ & 2.49 & 5 & 0.054 & 2.46 & 6 & 0.048 \\
\hline $\mathrm{Hg}$ & 0.99 & 5 & 0.441 & 8.03 & 6 & $<0.0001$ \\
\hline $\mathrm{Mn}$ & 3.42 & 5 & 0.015 & 1.07 & 6 & 0.402 \\
\hline $\mathrm{Zn}$ & 1.59 & 5 & 0.195 & 0.86 & 6 & 0.533 \\
\hline
\end{tabular}

of One-way analysis of variance (ANOVA) did not show any significant differences between the Fe values of the sites and months $(\mathrm{P}=0.054$ and $\mathrm{P}=0.048)$ Table 4 .

The water Hg values observed higher than the EPA normal levels in the June indicating water contamination to $\mathrm{Hg}$ in the June of the all site samplings (shown in bold in the Tables 1 and 2) whereas observed lower than the EPA normal levels ${ }^{20}$ in the other sites and months. The lowest and the highest water $\mathrm{Hg}$ contamination values observed in the $\mathrm{HH}$ and $\mathrm{SW}_{1}$, respectively both in the June (Tables 1 and 2, and Figure 1). The results of one-sample t-test revealed a significant differences between the $\mathrm{Hg}$ values of the sites and months with the EPA normal levels $(\mathrm{P}<0.0001)$ Table 3. Also The results of one-way analysis of variance (ANOVA) did not show any significant differences between the $\mathrm{Hg}$ values of the sites $(\mathrm{P}=0.441)$ Table 4, whereas showed a significant differences between the $\mathrm{Hg}$ values of the months $(\mathrm{P}<0.0001)$ Table 4 which is observed a significant differences between the $\mathrm{Hg}$ values of the June with the other months $(\mathrm{P}<0.05)$ followed by Post Hoc tests (Tukey HSD) and did not show any significant differences between the other months $(\mathrm{P}>0.05)$ Table 6.

The water Mn of the $\mathrm{SW}_{1}$ in the March, April and June; the $\mathrm{SW}_{4}$ in the December, March, June and September; the $\mathrm{SW}_{5}$ in the October, March, April, June and September; and the $\mathrm{HH}$ in the September observed higher than the
EPA normal levels indicating water contamination to $\mathrm{Mn}$ (shown in bold in the Tables 1 and 2) whereas observed lower than the EPA normal levels in the other months. The lowest and the highest water Mn contamination values observed in the $\mathrm{SW}_{1}$ and $\mathrm{SW}_{5}$ in the April and June, respectively (Tables 1 and 2, and Figure 1). The results of one-sample t-test showed a significant differences between the Mn values of the sites and months with the EPA normal levels $^{20}(\mathrm{P}<0.0001)$ Table 3. Also the results of One-way analysis of variance (ANOVA) showed a significant differences between the Mn values of the sites $(\mathrm{P}=0.015)$ Table 4 , whereas did not show any significant differences between the Mn values of the months $(\mathrm{P}<0.0001)$ Table 4 .

The $\mathrm{Zn}$ values of the $\mathrm{SW}_{5}$ in the October and September; and the HH in the March observed slightly lower than the EPA normal levels indicating water suspected to $\mathrm{Zn}$ contamination (shown in bold in the Tables 1 and 2) whereas observed lower than the EPA normal levels in the other sites and months.

The Pearson correlation analysis revealed a significant negative relationship between the water $\mathrm{Cr}$ values with the months $(\mathrm{P}<0.0001)$, whereas revealed a significant positive relationship between the water $F e$ and $M n$ values $(\mathrm{P}=0.004)$, and $\mathrm{Zn}$ values with sites $(\mathrm{P}=0.041)$ Table 7 .

In overall, as revealed in the Tables 1 and 2, and Figure 1, the water of Shadegan and Hawr Al Azim wetlands have been contaminated by $\mathrm{Cr}, \mathrm{Fe}, \mathrm{Mn}, \mathrm{Hg}$ and $\mathrm{Zn}$. In this respect contaminating the wetland waters by these heavy metals can adversely affect on human health of their water supply; also, it supports agricultural activities by providing a source of water for irrigation and livestock and for domestic consumption, sustainable forestry, nursery areas for juveniles of commercially valuable fish species and fisheries, forage resources, craft materials and medicinal plants; it also provides habitat for birds, which can play an important role in helping to control pests on nearby farms means that there is less need for costly and polluting chemical spraying to control insect pests. Also many bird, fish, mammal, reptile, and amphibian species are dependent to the wetlands for their breeding, foraging, and covering. Some species that they cannot survive elsewhere are providing by unique habitat of the special wetland conditions. Migratory birds depend on the wetlands. The life cycle of the many endangered and threatened species occur in the wetlands. Protection of threatened and endangered species is important in standards development ${ }^{13}$. However, this study showed that the water of these wetlands have been contaminated by heavy metals threatening their lives. 


\begin{tabular}{|c|c|c|c|c|c|c|c|c|c|c|c|}
\hline & $a$ & ' & ' & ' & ' & $\begin{array}{l}\tilde{I} \\
\stackrel{0}{0}\end{array}$ & ' & , & ' & , & $\begin{array}{l}\text { Oे } \\
0 \\
0 \\
0\end{array}$ \\
\hline $3^{n}$ & 岀 & ' & ' & & ' & $\begin{array}{l}\vec{D} \\
0 \\
0 \\
0\end{array}$ & ' & ' & ' & , & 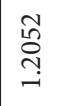 \\
\hline & 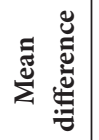 & ' & ' & & ' & 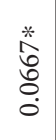 & ' & ' & ' & ' & 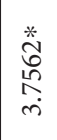 \\
\hline & $a$ & ' & , & ' & $\begin{array}{l}\circ \\
\stackrel{0}{0}\end{array}$ & $\stackrel{\tilde{o}}{0}$ & , & . & . & $\begin{array}{l}\tilde{o} \\
0 \\
0\end{array}$ & $\begin{array}{l}\hat{\sigma} \\
\hat{\sigma} \\
\hat{\Lambda}\end{array}$ \\
\hline $3^{3}$ & 密总 & ' & , & & $\begin{array}{l}\stackrel{9}{+} \\
\stackrel{2}{0} \\
0 \\
0\end{array}$ & $\begin{array}{l}\vec{D} \\
\infty \\
\vdots \\
0 \\
0\end{array}$ & . & . & ' & 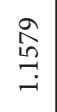 & ֶิ \\
\hline & 离 & & , & & $\begin{array}{l}\circ \\
0 \\
8 \\
0 \\
0\end{array}$ & 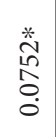 & ' & ' & ' & $\underset{m}{F}$ & To \\
\hline & a & ' & . & 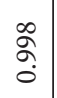 & $\begin{array}{l}\mathbb{3} \\
\stackrel{+}{0} \\
0\end{array}$ & $\vec{\Xi}$ & . & ' & $\begin{array}{l}\text { aे } \\
\hat{\Lambda}\end{array}$ & $\begin{array}{l}\stackrel{\mathrm{d}}{\mathrm{O}} \\
\text { ठ․ }\end{array}$ & $\begin{array}{l}\hat{\sigma} \\
\hat{\sigma} \\
\hat{\lambda}\end{array}$ \\
\hline $3^{m}$ & के & & ' & $\begin{array}{l}\stackrel{g}{+} \\
\stackrel{0}{0} \\
0\end{array}$ & $\begin{array}{l}\frac{2}{1} \\
\stackrel{0}{0} \\
0\end{array}$ & $\begin{array}{l}\overrightarrow{1} \\
\infty \\
\vdots \\
0 \\
0\end{array}$ & , & . & 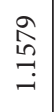 & 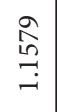 & గ̂̃ \\
\hline & 莺 & & , & $\begin{array}{l}\overrightarrow{\widehat{\sigma}} \\
\stackrel{0}{0} \\
\dot{0}\end{array}$ & $\begin{array}{l}0 \\
\stackrel{n}{0} \\
0 \\
0\end{array}$ & $\begin{array}{l}\stackrel{*}{*} \\
\stackrel{*}{1} \\
\stackrel{0}{0} \\
0\end{array}$ & ' & ' & $\begin{array}{c}\stackrel{\widehat{े}}{\tilde{\sigma}} \\
\text { }\end{array}$ & $\begin{array}{l}* \\
\hat{े} \\
\grave{0} \\
\infty \\
\dot{m}\end{array}$ & $\begin{array}{l}1 \\
0 \\
0 \\
0 \\
0\end{array}$ \\
\hline & a & . & $\begin{array}{l}\qquad \\
\infty \\
0 \\
0 \\
0\end{array}$ & $\begin{array}{l}\stackrel{n}{\tilde{q}} \\
\stackrel{0}{0}\end{array}$ & 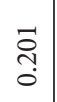 & $\begin{array}{l}\vec{\vdots} \\
\dot{0} \\
\dot{0} \\
\dot{v}\end{array}$ & , & $\begin{array}{l}\hat{\sigma} \\
\hat{\sigma} \\
\hat{\lambda}\end{array}$ & $\begin{array}{l}\hat{\alpha} \\
\hat{\alpha} \\
\hat{\Lambda}\end{array}$ & $\begin{array}{l}\stackrel{\grave{c}}{0} \\
\dot{0}\end{array}$ & $\begin{array}{l}2 \\
\hat{\sigma} \\
\hat{\alpha}\end{array}$ \\
\hline $3^{n}$ & 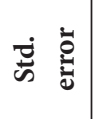 & , & $\begin{array}{l}\stackrel{2}{ \pm} \\
\stackrel{0}{0} \\
0\end{array}$ & $\begin{array}{l}\stackrel{2}{ \pm} \\
\stackrel{0}{0} \\
0\end{array}$ & $\begin{array}{l}\stackrel{2}{+} \\
\stackrel{0}{0} \\
0\end{array}$ & $\begin{array}{l}\overrightarrow{1} \\
\infty \\
\vdots \\
0 \\
0\end{array}$ & , & $\begin{array}{l}2 \\
\text { in } \\
= \\
-7\end{array}$ & $\begin{array}{l}2 \\
i \\
\\
\rightarrow\end{array}$ & 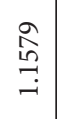 & ֶิ \\
\hline & 苞 & , & 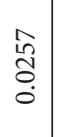 & 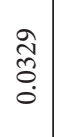 & $\begin{array}{l}\vec{H} \\
\overrightarrow{+} \\
\dot{0}\end{array}$ & $\begin{array}{l}\stackrel{*}{*} \\
\stackrel{0}{0} \\
\vdots \\
0\end{array}$ & ' & $\begin{array}{l}\vec{b} \\
\dot{0} \\
\dot{\dot{\theta}} \\
\dot{v}\end{array}$ & 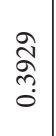 & 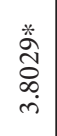 & $\begin{array}{l}1 \\
0 \\
0 \\
0 \\
0\end{array}$ \\
\hline & a & $\vec{\sigma}$ & ڤ̊ & $\begin{array}{l}\text { H } \\
\text { ó }\end{array}$ & $\begin{array}{l}\stackrel{+}{N} \\
\hat{0}\end{array}$ & $\begin{array}{l}\overrightarrow{\grave{Q}} \\
\dot{0} \\
\dot{\vec{v}}\end{array}$ & $\begin{array}{l}\hat{\alpha} \\
\hat{\alpha} \\
\hat{\lambda}\end{array}$ & 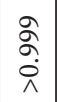 & $\begin{array}{l}\hat{\alpha} \\
\hat{\alpha} \\
\hat{\lambda}\end{array}$ & $\begin{array}{l}\text { o } \\
+ \\
0 \\
0\end{array}$ & $\begin{array}{l}\hat{\partial} \\
\dot{\hat{\lambda}} \\
\hat{\lambda}\end{array}$ \\
\hline 蔡 & 离蒡 & $\begin{array}{l}2 \\
+ \\
\vdots \\
0 \\
0\end{array}$ & $\begin{array}{l}\stackrel{g}{+} \\
\stackrel{0}{0} \\
0\end{array}$ & $\begin{array}{l}\stackrel{g}{+} \\
\stackrel{0}{0} \\
0\end{array}$ & $\begin{array}{l}\stackrel{g}{+} \\
\stackrel{0}{0} \\
0\end{array}$ & $\begin{array}{l}\vec{D} \\
\infty \\
\vdots \\
0 \\
0\end{array}$ & 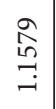 & $\begin{array}{l}2 \\
\text { in } \\
= \\
-7\end{array}$ & $\begin{array}{l}\stackrel{2}{\hat{n}} \\
\stackrel{-}{=} \\
=\end{array}$ & $\begin{array}{l}\stackrel{\overbrace{}}{\hat{n}} \\
\stackrel{0}{=} \\
=\end{array}$ & 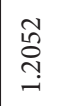 \\
\hline & 节 & $\begin{array}{l}\overrightarrow{5} \\
\stackrel{0}{0} \\
0\end{array}$ & $\begin{array}{l}\circ \\
0 \\
0 \\
\dot{0}\end{array}$ & $\begin{array}{l}\hat{n} \\
0 \\
0 \\
0\end{array}$ & 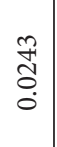 & 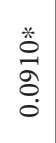 & $\begin{array}{l}+ \\
\overrightarrow{0} \\
\stackrel{-}{0}\end{array}$ & $\begin{array}{l}\vec{t} \\
\overrightarrow{0} \\
0 \\
0\end{array}$ & $\begin{array}{l}\overrightarrow{+} \\
\stackrel{n}{0} \\
\stackrel{0}{0}\end{array}$ & 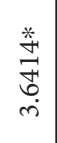 & 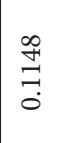 \\
\hline & $\overline{\frac{\pi}{2}}$ & 3 & $3_{\infty}^{m}$ & $3^{3}$ & $3^{i n}$ & 寻 & 3 & $3^{m}$ & $3^{+}$ & $3^{n}$ & 寻 \\
\hline & & \multicolumn{5}{|c|}{$\tilde{J}$} & \multicolumn{5}{|c|}{$\stackrel{\Xi}{\Sigma}$} \\
\hline
\end{tabular}

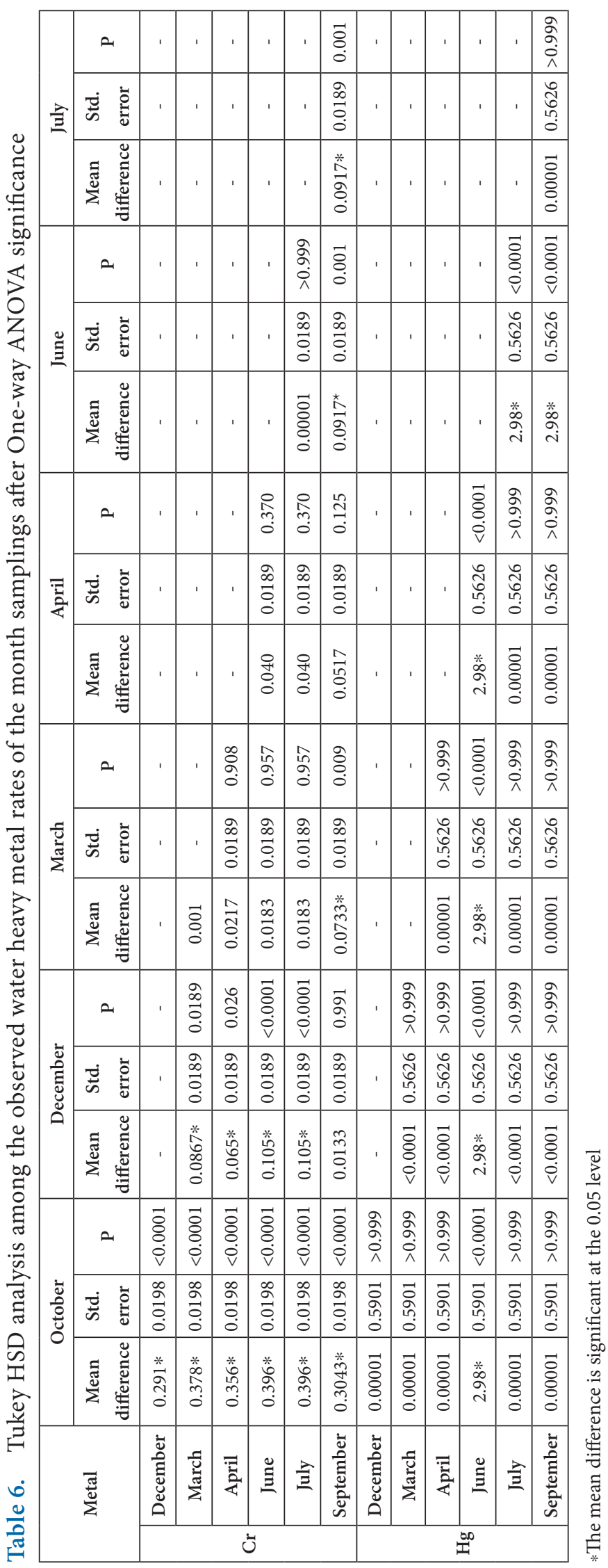


Table 7. Pearson correlation analysis among the water heavy metal, site and month samplings

\begin{tabular}{|c|c|c|c|c|c|c|c|}
\hline \multicolumn{2}{|r|}{ Metal } & $\mathrm{Fe}$ & $\mathrm{Hg}$ & Mn & Zn & Site & Month \\
\hline \multirow{3}{*}{$\mathrm{Cr}$} & Correlation & -0.225 & -0.214 & -0.140 & 0.174 & -0.214 & $-0.580^{* *}$ \\
\hline & Sig. & 0.157 & 0.178 & 0.382 & 0.276 & 0.178 & $<0.0001$ \\
\hline & $\mathrm{N}$ & 41 & 41 & 41 & 41 & 41 & 41 \\
\hline \multirow{3}{*}{$\mathrm{Fe}$} & Correlation & & 0.091 & $0.435^{* *}$ & 0.015 & 0.134 & 0.021 \\
\hline & Sig. & - & 0.573 & 0.004 & 0.924 & 0.404 & 0.897 \\
\hline & $\mathrm{N}$ & & 41 & 41 & 41 & 41 & 41 \\
\hline \multirow{3}{*}{$\mathrm{Hg}$} & Correlation & & & 0.059 & -0.089 & -0.205 & 0.149 \\
\hline & Sig. & - & - & 0.715 & 0.581 & 0.199 & 0.352 \\
\hline & $\mathrm{N}$ & & & 41 & 41 & 41 & 41 \\
\hline \multirow{3}{*}{ Mn } & Correlation & & & & 0.141 & 0.243 & 0.134 \\
\hline & Sig. & - & - & - & 0.380 & 0.126 & 0.405 \\
\hline & $\mathrm{N}$ & & & & 41 & 41 & 41 \\
\hline \multirow{3}{*}{$\mathrm{Zn}$} & Correlation & & & & & $0.320^{*}$ & -0.074 \\
\hline & Sig. & - & - & - & - & 0.041 & 0.647 \\
\hline & $\mathrm{N}$ & & & & & 41 & 41 \\
\hline \multirow{3}{*}{ Site } & Correlation & & & & & & 0.000 \\
\hline & Sig. & - & - & - & - & - & 1.000 \\
\hline & $\mathrm{N}$ & & & & & & 42 \\
\hline
\end{tabular}

**Correlation is significant at the 0.01 level (2-tailed).

*Correlation is significant at the 0.05 level (2-tailed).

Heavy metals in Shadegan and Hawr Al Hawizeh wetlands may come from natural as well as artificial sources. Heavy metals that are naturally introduced into these wetlands may come generally from weathering of rocks, erosion of soils and water-soluble salt dissolution. Naturally heavy metals introducing into aquatic environments independently of human activities usually have not detrimental effects. However, as Shadegan and Hawr Al Hawizeh wetlands are industrializing, the heavy metals introducing by human activities affect their water quality. Although some heavy metals may be vital for proper living organism metabolism but it is toxic at their high levels, others currently may be as non-essential but it is toxic even at relatively low levels. Heavy metals are released to Shadegan and Hawr Al Hawizeh wetlands are from numerous sources. Typical sources are municipal wastewater, manufacturing industries, mining, and agricultural cultivation and fertilization. They have increased their pollution leading to the deaths of its marine animals contaminated by heavy metals.

Although, these wetland waters have been contaminated by $\mathrm{Cr}, \mathrm{Fe}, \mathrm{Mn}, \mathrm{Hg}$ and $\mathrm{Zn}$, in this study, it can be considered that to be accumulated in the waterbed sedi- ment and bioconcentrated in the wildlife and animal tissues. These facts established by assessing some fish muscles and insect tissues that they had lived in the wetlands ${ }^{7,16,21,22}$ causing their high heavy metal pollution. Afterwards, their entering in the marine food chains they biomagnified there in the long periods. Then they fed by predator such as birds and fish and threatened human health through food chains by their human consuming. The heavy metals which are dissolved in the water have the greatest potential of causing the most deleterious toxic effects on organisms by their taken up. Various harmful effects including abnormal development of the fetus, procreation failure, and immunodeficiency have exhibited due to aquatic metal exposure ${ }^{12}$.

In the current study, the values of the $\mathrm{Cr}, \mathrm{Fe}, \mathrm{Mn}, \mathrm{Hg}$ and Zn were observed higher than the EPA water normal levels (shown as bold font style in Table 2), however Farrokhian et al. ${ }^{15}$ reported the water cadmium, lead, nickel and copper metal pollutants of the Shadegan wetland higher than the aquatic limits ${ }^{15}$. Also the values of the cadmium and lead metals in the fish muscle tissues in Hawr Al Azim wetland were determined. Results showed that some fish species were contaminated by high values of lead and cadmium ${ }^{21}$.

\section{Conclusion}

Shadegan and Hawr Al Azim wetlands have been contaminated by $\mathrm{Cr}, \mathrm{Fe}, \mathrm{Mn}, \mathrm{Hg}$ and $\mathrm{Zn}$ and they can be accumulated in the fauna and flora tissues. These facts established by assessing some fish muscles and insect tissues that they had lived in the wetlands bioaccumulated with high heavy metals. Such contamination might threatened human health through food chains.

\section{Acknowledgements}

The authors thank Tehran University of Medical Sciences for support to carry out this research.

\section{References}

1. A Primer on Water Quality. USGS (United States Geological Survey). U.S. Department of the Interior; FS-027-01; 2001 Mar. Available from: http://pubs.usgs.gov/fs/fs-027-01/

2. Sharma S, Sharma P. Biomonitoring of aquatic ecosystem with concept and procedures particular reference to aquatic macro invertebrates. Journal of American Science. 2010; 6(12):1246-55. 
3. EPA (Environmental Protection Agency). Wetlands. 2012. Available from: http://water.epa.gov/type/wetlands/index.cfm

4. Ramsar Convention Secretariat. The Ramsar convention manual: a guide to the convention on Wetlands (Ramsar, Iran, 1971). 5th edition Ramsar Convention Secretariat; Gland: Switzerland. 2011.

5. EPA (Environmental Protection Agency). Importance of Wetlands. 2010. Available from: http://www.epa.gov/bioiweb1/aquatic/importance.html

6. Constanza RR, D'Arge R, et al. The value of the world's ecosystem services and natural capital. Nature. 1997; 387:253-60.

7. Nasirian H. Using insects for heavy metal contamination survey in Shadegan Wetland. Thesis for fulfillment of the PhD Degree in Medical Entomology and Vector Control. School of Public Health; Tehran University of Medical Sciences; 2013.

8. Duffus JH. Heavy metals a meaningless term? (IUPAC Technical Report). Pure and Applied Chemistry. 2002; 74(5):793-807.

9. Jin L. Environmental Bionomy. First ed. High Education Press; Beijing. 1992.

10. Fargasova A. Comparative acute toxicity of $\mathrm{Cu}, \mathrm{Mn}, \mathrm{Mo}$, $\mathrm{Ni}$, and $\mathrm{V}$ to Chironomus plumosus larvae and Tubilfex worms. Biologia; 1998; 53:315-9.

11. Annabi A, Messaoudi I, et al. Comparative study of the sensitivity to cadmium of two populations of Gambusia affinis from two different sites. Environmental Monitoring and Assessment. 2009; 155(1-4): 459-65.

12. Chang XX, Wen $\mathrm{CH}$, et al. Effect of heavy metal pollution on human health and sustainable development. Yunnan Environmental Science. 2000; 19: 59.

13. EPA (Environmental Protection Agency). Office of Science and Technology. Strategy for water quality standards and criteria. Setting priorities to strengthen the foundation for protecting and restoring the nation's Waters; Publication EPA-823-R-03-010; 2003. Available from: http:// water.epa.gov/scitech/swguidance/standards/strategy/ upload/2003_08_28_standards_strategy_final.pdf

14. WHO (World Health Organization). Integrated Vector Management. WHO Regional Officer for Eastern Mediterranean; Cairo: Egypt. 2004.

15. Farrokhian F, Savari A, et al. Chemical quality of Shadegan wetland. Journal Environmental Studies. 1997; 19:13-24.

16. Nasirian H, Mahvi AH, et al. Study on the heavy metal bioconcentration of the Shadegan international wetland mosquitofish, Gambusia affinis, by inductively coupled plasma technique. Journal of Environmental Health Science and Engineering. 2013; 11:22.

17. Mirzaei R, Conroy J, et al. Otters in the Hawr Al Azim wetland, Iran. Hystrix, Italian Journal of Mammalogy. 2010; 21(1):83-8.

18. Nasirian H. Evaluation of water quality and organic pollution of Shadegan and Hawr Al Azim wetlands by biological indices using insects. Journal of Entomology and Zoology Studies. 2014; 2(5):193-200.

19. Nasirian H, Nasirian Z, et al. Use of inductively coupled plasma-mass spectrometry, ICP-MS, in entomology. International Journal of Entomological Research. 2014; 2(2): 47-57.

20. EPA (Environmental Protection Agency). Water: drinking water contaminants. 2012. Available from: http://water. epa.gov/drink/contaminants/index.cfm

21. Fatemi SMR, Hamidi Z. Determination of cadmium and lead levels in muscle tissue of some edible fishes in HourAl-Azim wetland. Journal of Fisheries. 2010; 4(1):1-7.

22. Nasirian $H$, Vazirianzadeh B, et al. Culiseta subochrea as a bioindicator of metal contamination in Shadegan international wetland, Iran (Diptera: Culicidae). Journal of Insect Science. 2014; 14:258. 